\title{
Andrzej Kierzek, Uzdrowiska nadniemeńskie dawniej, Oficyna Wydawnicza "Atut", Wrocław 2017, ss. 218. Wydanie I, ISBN 978-83-7977-293-3.
}

Czytelnik już na wstępie zna wyraźnie określony cel, jaki stawia przed sobą Andrzej Kierzek, decydując się na publikacje niniejszej książki. Wskazuje na praktyczna potrzebę zebrania w całość powstałych na przestrzeni siedmiu lat tekstów będacych wynikiem współpracy grupy autorów, a dotyczacych rozwoju lecznictwa uzdrowiskowego położonych nad Niemnem Birszantach, Druskiennikach, Stokliszkach i Niemonajciach do chwili wybuchu II wojny światowej. Prócz Andrzeja Kierzka współtwórcami zamieszczonych w książce tekstów sa: Małgorzata Paprocka-Borowicz, Andrzej Pozowski, Jadwiga Kuciel-Lewandowska.

Taki zabieg wydaje się ze wszech miar korzystny i uzasadniony, zwłaszcza, że zgromadzony materiał był publikowany $\mathrm{w}$ formie odrębnych artykułów na łamach różnych czasopism - „Przegląd Lekarski”, „Annales Academiae Medicae Stetinensis”, "Acta Balneologica”, „Pielęgniarstwo i Zdrowie Publiczne”, „Archiwum Historii i Filozofii Medycyny”, „Pamiętnik Towarzystwa Lekarskiego Warszawskiego” czy „Współczesne Pielęgniarstwo i Ochrona Zdrowia”. Dwa teksty pochodzą z kolejnych dwóch tomów zbioru Szkice z historii medycyny pod redakcja Jerzego Supadego. Ponowne ich wydanie $\mathrm{w}$ odrębnym zbiorze $\mathrm{z}$ pewnością ułatwi szeregu czytelnikom zainteresowanym tą problematyką zapoznanie się z ciekawymi faktami, a także pozwoli na zyskanie dla siebie nowej, jakże barwnej perspektywy nadniemeńskiej tradycji uzdrowiskowej. Nie jest to bowiem li tylko świat lekarzy i medycyny, choć siła rzeczy jest on w wielu miejscach dominujący, lecz również opowieść o kuracjuszach, życiu towarzyskim, historii literatury. By rzecz całą uczynić przejrzystą dla odbiorcy zaproponowano sześć głównych watków tematycznych, którym nadano formę osobnych rozdziałów.

Pierwszy, będący wprowadzeniem w „nadniemieńskie klimaty”, jest historią najsławniejszego z tamtejszych uzdrowisk - uzdrowiska w Druskiennikach, którego początki sięgają czasów Stanisława Augusta Ponaitowskiego. W drugim zaprezentowano sylwetki tych lekarzy, dzięki którym Druskienniki nabrały pierwszorzędnego znaczenia jako miejsce leczenia szeregu zdrowotnych dolegliwości. Rzecz tym bardziej godna uwagi, że prócz danych biograficznych zaprezentowano i po części poddano analizie dorobek naukowy i popularyzatorski druskiennickich balneologów; Ksawerego Wolfganga, pomysłodawce, redaktora i wydawce „Ondyny Druskiennickich Źródeł”, periodyku łączącego w sobie zarówno tradycję lekarska, jak i historyczną i literacka, Izydora Nahumowicza, autora bogatej w informacje wszelakie książki Sposób leczenia się mineralnymi wodami w Druskiennikach (Grodno 1841), Anicentego Reniera badającego i propagującego $\mathrm{w}$ wileńskim środowisku lekarskim zastosowania wód leczniczych z Druskiennik czy też Kazimierza Chońskiego oraz wytrawnego praktyka i znakomitego społecznika Jana Pileckiego i Walerego Bujakowskiego, nowoczesnego balneologa, skrupulatnie badajacego pozytywne i negatywne skutki stosowania 
terapii znanych ówcześnie źródeł. Nieco krótsze noty zamieszczono o kilkunastu jeszcze lekarzach, którzy w różnym stopniu wiązali swoje losy z uzdrowiskiem.

W rozdziale trzecim uwagę czytelnika skierowano na praktykę otolaryngologiczna wiążącą się ściśle z tradycją Druskiennik oraz na sławny zarówno ze względu na doskonałą organizację, jak i z racji osoby jego patronki, doktor Eugenii Lewickiej, zakład leczniczy. Nie mniej ciekawie rysuje się rozdział czwarty zatytułowany „Kuracjusze u wód" otwierający przed nami drzwi do świata pacjentów i chorych, w tym również tych znanych, na trwałe wpisanych do historii polskiej kultury; Józefa Ignacego Kraszewskiego i Elizę Orzeszkowa. Ważnym przypomnieniem są losy późno powstałego, gdyż dopiero w 1926 roku, Towarzystwa Lekarskiego Druskiennickiego, którego historia gwałtownie się urywa w 1939 roku. Dopełnieniem całości jest rozdział szósty i ostatni, na który składają się szkice poświęcone uzdrowiskom w Birszantach, Stokliszkach i Niemonajciach. Książkę opatrzono też krótkim posłowiem.

Mocną stroną recenzowanej książki jest częste powoływanie się na teksty źródłowe wraz z ich analizą. W zgodzie z przyjętymi zasadami dla opracowań badawczych dobrze wykorzystano dostępną bibliografię. Całość opatrzono dodatkowo ponad trzydziestoma rycinami, co niewatpliwie pozwala odbiorcy jeszcze lepiej wczuć się w klimat tamtego, istniejaccego już wyłącznie na kartach papieru i kliszach fotograficznych świata. Jak zostało to wyraźnie podkreślone we wstępie przez redagującego całość Andrzeja Kierzka wprowadzono pewne korekty w stosunku do oryginalnych tekstów artykułów, tak aby uniknąć niepotrzebnych powtórzeń i ujednolicić całość pod względem stylistycznym. Nie zdecydowano się natomiast na ujednolicenie struktury przywoływanych cytowań, zachowując je w takiej formie - przypisy dolne lub końcowy zbiór piśmiennictwa, jakie narzucone były autorom tekstów przez wymogi poszczególnych redakcji czasopism. Jakkolwiek nie powinno to nadmiernie przeszkadzać w samej lekturze książki, to jednak przez metodologicznych purystów może być postrzegane jako uchybienie. Nie zmienia to w niczym dobrego wrażenia jakie ze soba niesie lektura poszczególnych rozdziałów. Na pewno warto po tę pozycję sięgnać.

Ryszard W. Gryglewski

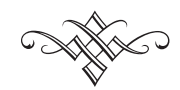

